\title{
Analisis Potensi Penerimaan Pajak Air Tanah Dan Kontribusinya Terhadap Penerimaan Pajak Daerah Kota Kendari
}

\author{
Oleh \\ Tuti Dharmawati $^{1}$, Mulyati Akib ${ }^{2}$, Darman Setiaji ${ }^{3}$ \\ Email:Setiajidarman.acc@gmail.com
}

\begin{abstract}
This study aims to determine the potential groundwater tax revenue and the contribution of groundwater tax revenue to the Kendari City regional tax revenue in 2015-2018. The type of data used in this study are quantitative and qualitative data, the source of the data used are secondary data and primary data. The data collection method in this research uses interviews, documentation and literature study. Analysis of the data used is descriptive analysis.

The results of this study indicate that the potential for groundwater tax revenues is far greater than the realization received by the Kendari City Regional Tax and Retribution Management Agency. There is an increase in the potential for groundwater tax revenue from 2015-2018 by 18\% and the contribution of groundwater tax revenue to the Kendari City regional tax revenue from 2015-2018 is categorized as very less contributing with an average value of $0.37 \%$.
\end{abstract}

Keywords: Potential, Contribution, Groundwater Tax, Local Tax Revenue

\section{PENDAHULUAN}

Pajak menjadi komponen paling penting dalam perekonomian Indonesia, karena pajak menjadi sumber penerimaan terbesar negara. Sumber pembiayaan terbesar yang ideal dalam penyelenggaraan pemerintah daerah ialah Pendapatan Asli Daerah (PAD). Pendapatan asli daerah (PAD) adalah penerimaan yang di peroleh daerah dari sumber-sumber dalam wilayahnya sendiri yang dipungut berdasarkan peraturan daerah sesuai dengan perundang-undangan yang berlaku. Salah satu pos pendapatan asli daerah (PAD) dalam Anggaran Pendapatan dan Belanja Daerah (APBD) adalah pajak daerah.

Salah satu pajak daerah yang memiliki potensi cukup besar untuk menambah pendapatan asli daerah adalah pajak air tanah. Pajak air tanah adalah pajak atas pengambilan dan pemanfaatan air tanah untuk keperluan usaha atau komersial. Pajak air tanah merupakan pajak yang terbilang prospektif dimasa mendatang. Dari tahun ke tahun pemakaian dan pemanfaatan air khususnya air tanah terus mengalami peningkatan dan menjadi kebutuhan paling mendasar. Selain dimanfaatkan untuk keperluan dasar rumah tangga, air tanah juga digunakan dan dimanfaatkan untuk menunjang keperluan usaha dan industri.

Kota Kendari adalah salah satu kota yang usaha dan industrinya sedang mengalami pertumbuhan yang diikuti dengan meningkatnya kebutuhan akan penggunaan air tanah sebagai sumber air bersih untuk keperluan operasional usaha baik itu sebagai usaha penunjang maupun usaha inti. Berikut adalah data yang di peroleh dari Badan Pengelola Pajak dan Retribusi Daerah Kota Kendari mengenai jumlah wajib pajak air tanah tahun 2015-2018 sebagai berikut: 
Tabel 1.1 Wajib Pajak Air Tanah

\begin{tabular}{|c|c|}
\hline TAHUN & JUMLAH (ORANG/BADAN) \\
\hline 2015 & 159 \\
\hline 2016 & 149 \\
\hline 2017 & 149 \\
\hline 2018 & 183 \\
\hline
\end{tabular}

Sumber Data: Badan Pengelola Pajak dan Retribusi Daerah Kota Kendari

Berdasarkan tabel diatas dapat dilihat jumlah wajib pajak air tanah Kota Kendari cenderung meningkat.

Tabel 1.2 Target dan Realisasi Penerimaan Pajak Air Tanah Kota Kendari Tahun 2015-2018

\begin{tabular}{|c|c|c|c|}
\hline Tahun & Target $(\mathbf{R p )}$ & Realisasi (RP) & Persentase (\%) \\
\hline 2015 & $300.000 .000,00$ & $307.641 .400,00$ & 102,55 \\
\hline 2016 & $300.000 .000,00$ & $333.641 .500,00$ & 111,21 \\
\hline 2017 & $350.000 .000,00$ & $358.150 .100,00$ & 102,33 \\
\hline 2018 & $550.000 .000,00$ & $389.705 .800,00$ & 70,86 \\
\hline
\end{tabular}

Sumber Data : Badan Pengelola Pajak dan Retribusi Daerah Kota Kendari

Pada tabel 1.2 juga dapat dilihat bahwa dari tahun 2015-2017 realisasi penerimaan pajak air tanah selalu melewati target. Akan tetapi pada tahun 2018 realisasi penerimaan pajak air tanah tidak mencapai target. Berdasarkan hasil wawancara dengan salah satu pegawai pada Badan Pengelola Pajak dan Retribusi Daerah, tidak tercapainya target peneriman pajak air tanah pada tahun 2018 dikarenakan perhitungan volume air yang digunakan oleh wajib pajak air tanah masih manual sehingga penerimaan yang diperoleh tidak maksimal dan ada juga beberapa wajib pajak menunggak pembayaran.

Jika melihat jumlah wajib pajak kota kendari pada tabel 1.1, Angka tersebut tidak realistis dengan kondisi sebenarnya yang terjadi di lapangan. Faktanya adalah masih banyak tempat usaha yang mengambil atau memanfaatkan air tanah untuk keperluan komersial tetapi tidak terdaftar sebagai wajib pajak air tanah. Hal ini mengindikasikan bahwa potensi pajak air tanah cukup besar dan perlu digali lagi oleh Badan Pengelola Pajak dan Retribusi Daerah Kota Kendari.

Berdasarkan latar belakang masalah dan uraian diatas, maka penulis tertarik untuk melakukan penelitian dengan judul "Analisis Potensi Penerimaan Pajak Air Tanah dan Kontribusinya Terhadap Penerimaaan Pajak Daerah Kota Kendari”.

\subsection{Kajian Teori}

\section{KAJIAN PUSTAKA}

\subsubsection{Defenisi Pajak}

Menurut Prof. Dr. Rochmat Soemitro, S.H. dalam buku Mardiasmo (2018:3), "Pajak adalah iuran rakyat kepada kas negara berdasarkan Undang-Undang (yang dapat dipaksakan) dengan tidak mendapat jasa timbal (kontraprestasi) yang langsung dapat ditunjukan dan yang digunakan untuk membayar pengeluaran umum”.

\subsubsection{Fungsi Pajak}

Mardiasmo (2018:4) pajak memiliki 2 fungsi yaitu sebagai berikut:

1. Fungsi anggaran (budgetair) Pajak berfungsi sebagai salah satu sumber dana bagi pemerintah untuk membiayai pengeluaran-pengeluarannya.

2. Fungsi mengatur (regulerend) 
Pajak berfungsi sebagai alat untuk pengatur atau melaksanakan kebijaksanaan pemerintah dalam bidang sosial dan ekonomi

\subsubsection{Syarat Pemungutan Pajak}

Agar pemungutan pajak tidak menimbulkan hambatan atau perlawanan, maka pemungutan pajak harus memenuhi syarat-syarat sebagai berikut (Mardiasmo, 2018:4-5):

1. Pemungutan pajak harus adil (syarat keadilan)

2. Pemungutan pajak harus berdasarkan Undang-Undang (syarat yuridis)

3. Tidak menganggu perekonomian (Syarat Ekonomis)

4. Pemungutan pajak harus efisien (Syarat Finansial)

5. Sistem pemungutan pajak harus sederhana

\subsubsection{Sistem Pemungutan Pajak}

Menurut Mardiasmo (2018:9) sistem pemungutan pajak dapat dibagi menjadi 3 tiga sistem yaitu sebagai berikut:

1. Official Assesment Sistem, adalah suatu sistem pemungutan yang memberikan kewenangan kepada pemerintah (fiskus) untuk menentukan besarnya pajak.

2. Self assesment system adalah suatu sistem pemungutan yang memberi wewenang seluruhnya kepada wajib pajak untuk menghitung, memperhatikan, membayar , melapokan sendiri besarnya pajak terutang

3. With Holding system adalah suatu sistem pemungutan yang memberi wewenang kepada pihak ketiga (bukan fiskus dan bukan wajib pajak) untuk menentukan besarnya pajak yang terutang oleh wajib pajak.

\subsubsection{Tarif Pajak}

Menurut Mardiasmo (2018:11-12), ada 4 macam tarif pajak yaitu sebagai berikut:

1. Tarif Sebanding/Proporsional, tarif berupa presentase yang tetap terhadap berapapun jumlah yang dikenai pajak, sehingga besarnya pajak yang terutang proporsional terhadap besarnya nilai yang dikenai pajak.

2. Tarif Tetap, tarif berupa jumlah yang tetap (sama) terhadap berapa pun jumlah yang dikenai pajak, sehingga besarnya pajak yang terutang tetap.

3. Tarif Progresif, persentase tarif yang digunakan semakin besar bila jumlah yang dikenai pajak semakin besar.

4. Tarif Degresif, persentase tarif yang digunakan semakin kecil bila jumlah yang dikenai pajak semakin besar.

\subsection{Pendapatan Asli Daerah}

\subsubsection{Pengertian Pendapatan Asli Daerah}

Menurut Mardiasmo (2018), "Pendapatan asli daerah adalah penerimaan daerah dari sektor pajak daerah, retribusi daerah, hasil pengelolaan kekayaan daerah yang dipisahkan, hasil perusahaan milik daerah, dan lain-lain pendapatan asli daerah yang sah".

\subsubsection{Sumber Pendapatan Asli Daerah}

Terdapat empat sumber yang menjadi sumber Pendapatan Asli daerah menurut Undang-Undang No. 33 Tahun 2004 tentang Perimbangan Keuangan antara Pemerintah Pusat dan Pemerintah Daerah, diantaranya yaitu:

1. Pajak Daerah

2. Retribusi Daerah

3. Hasil Pengelolaan Kekayaan Daerah yang Dipisahkan

4. Lain-lain Pendapatan Asli Daerah yang sah 


\subsection{Pajak Daerah}

\subsubsection{Defenisi Pajak Daerah}

Pajak Daerah dalam Undang-Undang Nomor 28 Tahun 2009 tentang Pajak Daerah dan Retribusi Daerah adalah kontribusi wajib kepada daerah yang terutang oleh orang pribadi atau badan yang bersifat memaksa berdasarkan undang-undang, dengan tidak mendapat imbalan secara langsung dan digunakan untuk keperluan daerah bagi sebesarbesarnya kemakmuran rakyat.

\subsubsection{Jenis Pajak Daerah}

Undang-Undang Nomor 28 Tahun 2009 tentang Pajak Daerah dan Retribusi Daerah terdapat 5 jenis pajak provinsi dan 11 jenis pajak kabupaten/kota.

1. Pajak provinsi terdiri dari: Pajak Kendaraan Bermotor, Bea Balik Nama Kendaraan Bermotor, Pajak Bahan Bakar Kendaraan Bermotor, Pajak Air Permukaan, Pajak Rokok.

2. Pajak Kabupaten/Kota terdiri dari: pajak hotel, pajak restoran, pajak hiburan, pajak reklame, pajak penerangan jalan, pajak mineral bukan logam dan batuan, pajak parkir, pajak air tanah, pajak sarang burung walet, pajak bumi dan bangunan, bea perolehan hak atas tanah dan bangunan

\subsection{Pajak Air Tanah}

\subsubsection{Pengertian Pajak Air Tanah}

Menurut pasal 1 ayat 33 Undang-Undang No. 28 Tahun 2009, "Pajak Air Tanah adalah pajak atas pengambilan dan/atau pemanfaatan air tanah. Kemudian ayat berikutnya dijelaskan bahwa yang dimaksud dengan air tanah adalah air yang terdapat dalam lapisan tanah atau batuan dibawah permukaan tanah".

\subsubsection{Dasar Hukum Pemungutan Pajak Air Tanah}

Pemungutan pajak air tanah di Indonesia pada saat ini didasarkan pada dasar hukum yang sesuai dengan perundang-undangan, dimana dasar hukum tersebut jelas dan kuat sehingga harus dipatuhi oleh semua masyarakat dan pihak-pihak yang terkait. Dasar pemungutan pajak air tanah pada Kota Kendari adalah sebagai berikut:

1. Undang-Undang Nomor 28 Tahun 2009 tentang Pajak Daerah dan Retribusi Daerah.

2. Peraturan Daerah Kota Kendari Nomor 2 Tahun 2011 tentang Pajak Daerah.

3. Peraturan Walikota Kendari Nomor 11 Tahun 2015 tentang Nilai Perolehan Air Tanah Sebagai Dasar Pengenaan Pajak Pengambilan dan Pemanfaatan Pajak Air Bawah Tanah.

\subsubsection{Objek Pajak Air Tanah}

Objek pajak air tanah adalah adalah pengambilan dan/atau pemanfaatan air tanah baik secara langsung ataupun tidak langsung yang dikomersialkan. Dikecualiakan dari objek pajak air tanah adalah:

a. Pengambilan dan pemanfaatan air tanah untuk keperluan dasar rumah tangga, pengairan pertanian, dan perikanan rakyat serta peribadatan.

b. Pengambilan dan/atau pemanfaatan air tanah oleh pemerintah

\subsubsection{Subjek dan Wajib Pajak Air Tanah}

Berdasarkan Peraturan Daerah Kota Kendari Nomor 2 Tahun 2011 Pasal 39 Subjek pajak air tanah adalah orang pribadi atau Badan yang melakukan pengambilan dan atau pemanfaatan air tanah. Sedangkan wajib pajak air tanah yaitu orang atau Badan yang melakukan pengambilan dan/atau pemanfaatan air tanah. 


\subsubsection{Dasar Pengenaan Pajak Air Tanah}

Dasar pengenaan pajak air tanah dijelaskan dalam Peraturan Daerah Kota Kendari Nomor 2 tahun 2011 pasal 40 yaitu sebagai berikut:

1. Dasar pengenaan pajak air tanah adalah nilai perolehan air tanah.

2. Nilai perolehan air tanah sebagaimana yang dimaksud sebelumnya dinyatakan dalam rupiah yang dihitung dengan mempertimbangkan sebagian atau seluruh faktor-faktor berikut:

a. Jenis sumber air

b. Lokasi sumber air

c. Tujuan pengambilan dan pemanfaatan air

d. Volume air yang diambil atau dimanfaatkan

e. Kualitas air

f. Tingkat kerusakan lingkungan yang diakibatkan oleh pengambilan atau pemanfaatan air tanah.

3. Penggunaan faktor-faktor perolehan air tanah disesuaikan dengan kondisi daerah dan besaran nilai perolehan air tanah ditetapkan dengan Peraturan Kepala Daerah

\subsubsection{Tarif Pajak Air Tanah}

Berdasarkan Peraturan Daerah Kota Kendari Nomor 2 Tahun 2011 Pasal 41 tentang Pajak Daerah, tarif pajak air tanah ditetapkan sebesar $20 \%$.

\subsection{Potensi}

Potensi berasal dari bahasa inggris yaitu potency yang merupakan sesuatu yang sebenarnya sudah ada tapi belum dapat tergali. Potensi adalah kemampuan dari diri seseorang atau hal lain yang dapat digali dan atau bahkan dikembangkan (Kesit, 2005:142). Potensi pajak air tanah bisa diartikan sebagai kekuatan yang sudah dimiliki tapi belum bisa diraih secara maksimal atau seratus persen dari perolehan pajak air tanah.

\subsection{Kontribusi}

Menurut KBBI pengertian kontribusi adalah sumbangan. Kontribusi digunakan untuk mengetahui seberapa besar sumbangan atau peran penerimaan pajak air tanah terhadap penerimaan pajak daerah atau sejauh mana penerimaan pajak air tanah memberikan sumbangan dan perannya dalam pendapatan asli daerah. 


\subsection{Kerangka Pikir Penelitian}

\section{Skema 2.1 Kerangka Pikir}

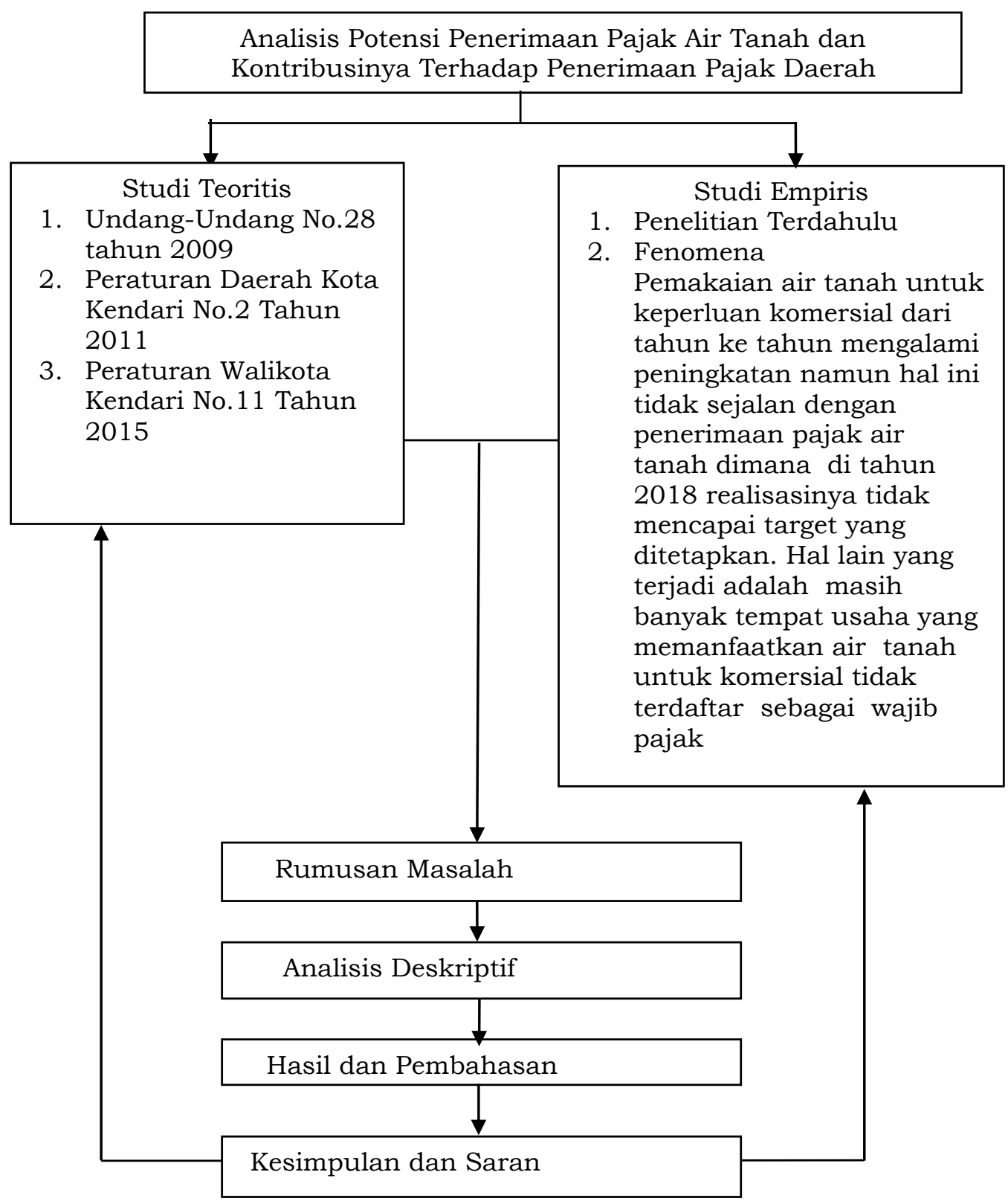

\section{METODE PENELITIAN}

Objek penelitian yang menjadi fokus dalam penelitian ini adalah potensi pajak air tanah dan kontribusi pajak air tanah serta penerimaan pajak daerah. Lokasi penelitian dilakukan pada Badan Pengelola Pajak dan Retribusi Daerah Kota Kendari yang beralamat di jalan Drs. H. Abdullah Silondae Nomor 8 Kota Kendari Sulawesi Tenggara.

Sampel dalam penelitian ini disebut sebagai narasumber atau informan. Teknik sampling yang digunakan dalam penelitian adalah purposive sampling. Purposive sampling adalah teknik pengambilan sampel sumber data dengan karasteristik tertentu. Karakteristik sampel yang digunakan dalam penelitian ini adalah sebagai berikut:

1. Pegawai pada Badan Pengelola Pajak dan Retribusi Daerah Kota Kendari

2. Wajib Pajak air tanah di Kota Kendari 
Adapun yang menjadi informan dalam penelitian ini adalah :

1. Koordinator lapangan pajak air tanah

2. Pemilik usaha yang mengambil dan memanfaatkan air tanah untuk komersial sebanyak 10 orang

Jenis data dalam penelitian ini adalah data kuantitatif dan data kualitatif. Data kuantitatif dalam Penelitian ini adalah data mengenai target dan realisasi penerimaan pajak air tanah, target dan realisasi penerimaan pajak daerah serta jumlah wajib pajak air tanah Kota Kendari tahun 2015-2018. data kualitatif yaitu informasi yang diperoleh dari wawancara langsung dengan pihak terkait pemungutan pajak air tanah pada Badan Pengelola Pajak dan Retribusi Daerah Kota Kendari.

Sumber data dalam penelitian ini yaitu data primer dan data sekunder. Data primer bersumber dari wawancara kepada pihak-pihak yang terkait dan berhubung yang dapat menunjang dalam penelitian ini. Data sekunder berupa data dokumentasi atau dokumendokumen pada Badan Pengelola Pajak dan Retribusi Daerah Kota Kendari dan pihak lainnya yang menunjang penelitian ini.

Metode pengumpulan data dalam penelitian ini yaitu wawancara, dokumentasi dan studi kepustakaan. Wawancara dilakukan secara langsung dengan bertemu pihak-pihak yang terkait dan berkompeten terhadap data yang dibutuhkan peneliti dan relevan dengan masalah penelitian. Dokumentasi yaitu mengumpulkan data dengan menggunakan arsip atau dokumen yang bersifat tulisan dari instansi yang bersangkutan. Studi kepustakaan mengumpulkan data dan menganalisis sumber informasi baik yang berupa jurnal ilmiah, buku, artikel, ketentuan dalam undang-undang perpajakan, maupun informasi lain yang relevan dengan penelitian ini.

Metode analisis data yang digunakan adalah metode analisis deskriptif. Penelitian deskriptif adalah suatu penelitian yang dilakukan untuk mengumpulkan informasi mengenai status gejala yang ada, yaitu keadaan gejala apa adanya pada saat penelitian dilakukan. Hasil analisis tersebut kemudian diinterpretasikan guna memberikan gambaran yang jelas terhadap permasalahan yang diajukan.

1. Perhitungan potensi :

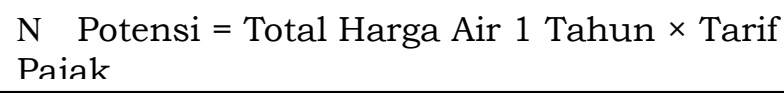

Sumber : Harun, 2003:10

2. Perhitungan Kontribusi

$$
\text { Kontribusi }=\frac{\text { realisasi penerimaan pajak air tanah tahun ke } \mathrm{n}}{\text { realisasi penerimaan pajak daerah tahun ke } \mathrm{n}} \times 100 \%
$$

(Sumber : Halim, 2007)

Tabel 3.1 Kriteria Kontribusi

\begin{tabular}{|c|c|}
\hline Klasifikasi Kontribusi & Kriteria \\
\hline $0-0,9 \%$ & Sangat Kurang Berkontribusi \\
\hline $1-1,9 \%$ & Kurang Berkontribusi \\
\hline $2-2,9 \%$ & Cukup Berkontribusi \\
\hline $3-3,9 \%$ & Berkontribusi \\
\hline Diatas $4 \%$ & Sangat Berkontribusi \\
\hline
\end{tabular}

Sumber : Handoko, 2013 


\section{HASIL PENELITIAN DAN PEMBAHASAN}

\subsection{Hasil Penelitian}

\subsubsection{Analisis Potensi Pajak Air Tanah}

Untuk menghitung potensi penerimaan pajak air tanah yang bisa diterima Kota Kendari langkah pertama adalah mengelompokan wajib pajak berdasarkan subjek pemakai atau kelompok pemakai air tanah yang dapat dilihat sebagai berikut:

Tabel 4.1 Kelompok Pemakai dan Jumlah Wajib Pajak Air Tanah 2015-2018

\begin{tabular}{|l|c|c|c|c|}
\hline $\begin{array}{c}\text { Kelompok Pemakai } \\
\text { Air Tanah }\end{array}$ & $\mathbf{2 0 1 5}$ & $\mathbf{2 0 1 6}$ & $\mathbf{2 0 1 7}$ & $\mathbf{2 0 1 8}$ \\
\hline Non niaga & 1 & 1 & 1 & 1 \\
\hline Niaga Kecil & 66 & 59 & 59 & 65 \\
\hline Industri Kecil & 0 & 0 & 0 & 0 \\
\hline Niaga Besar & 90 & 87 & 87 & 115 \\
\hline Industri Besar & 2 & 2 & 2 & 2 \\
\hline \multicolumn{1}{|c|}{ Total } & $\mathbf{1 5 9}$ & $\mathbf{1 4 9}$ & $\mathbf{1 4 9}$ & $\mathbf{1 8 3}$ \\
\hline
\end{tabular}

Sumber: Badan Pengelola Pajak dan Retribusi Daerah Kota Kendari (data diolah

Berdasarkan Hasil Wawancara dengan kordinator lapangan pajak air tanah Badan

Pengelola Pajak dan Retribusi Daerah :

1. Rata-rata maksimal pengambilan air tanah
Non Niaga
$: 259 \mathrm{~m}^{3}$
Niaga Kecil
$: 250 \mathrm{~m}^{3}$
Niaga Besar
: $300 \mathrm{~m}^{3}$
Industri Besar
: $1400 \mathrm{~m}^{3}$

2. Masa pajak yaitu 1 Bulan

3. Harga Dasar Air

Harga dasar air diperoleh dari Harga Air Baku $(\mathrm{HAB}) \times$ Faktor Nilai Air ( Fn-Air) sesuai dengan Peraturan Walikota Kendari No. 11 Tahun 2015. Penetapan harga air baku berdasarkan dari diamater lubang pipa (1-3 inchi) dan pipa yang digunakan (PVC). Sementara Faktor Nilai Air ditetapkan berdasarkan kriteria apakah air tanah yang digunakan berkualitas baik, ada sumber alternatif PDAM atau tidak dan melihat volume penggunaan air tanah.

Adapun perhitungan potensi pajak air tanah dapat dihitung dengan menggunakan rumus (Harun, 2004:10) yaitu total harga air satu tahun dikalikan dengan tarif pajak air tanah yaitu sebesar $20 \%$. Sementara untuk total harga air satu tahun diperoleh dari hasil perkalian antara jumlah objek pajak, maksimal pengambilan air, harga dasar air, serta jumlah bulan dalam satu tahun. Berikut adalah penyajian data terkait dengan potensi pajak air tanah tahun 2015-2018 Kota Kendari:

Tabel 4.2 Total Harga Air Tanah Tahun 2015-2018 Non Niaga

\begin{tabular}{|c|c|c|c|c|c|}
\hline Tahun & $\begin{array}{c}\text { Jumlah } \\
\text { Objek Pajak }\end{array}$ & $\begin{array}{c}\text { Maksimal } \\
\left(\mathbf{m}^{\mathbf{3}}\right)\end{array}$ & $\begin{array}{c}\text { Harga Dasar } \\
\text { Air }(\mathbf{R p})\end{array}$ & $\begin{array}{c}\text { Jumlah } \\
\text { Bulan }\end{array}$ & Jumlah (Rp) \\
\hline $\mathbf{1}$ & $\mathbf{2}$ & $\mathbf{3}$ & $\mathbf{4}$ & $\mathbf{5}$ & $\mathbf{6}(\mathbf{2} \times \mathbf{3} \times \mathbf{4} \times \mathbf{5})$ \\
\hline 2015 & 1 & 259 & 1781 & 12 & $5.535 .348,00$ \\
\hline 2016 & 1 & 259 & 1781 & 12 & $5.535 .348,00$ \\
\hline 2017 & 1 & 259 & 1781 & 12 & $5.535 .348,00$ \\
\hline 2018 & 1 & 259 & 1781 & 12 & $5.535 .348,00$ \\
\hline
\end{tabular}

Sumber: Badan Pengelola Pajak dan Retribusi Daerah Kota Kendari (data diolah) 
Tabel 4.3 Total Harga Air Tanah Tahun 2015-2018 Niaga Kecil

\begin{tabular}{|c|c|c|c|c|c|}
\hline Tahun & $\begin{array}{c}\text { Jumlah } \\
\text { Objek } \\
\text { Pajak }\end{array}$ & $\begin{array}{c}\text { Maksimal } \\
\left(\mathbf{m}^{\mathbf{3}}\right)\end{array}$ & $\begin{array}{c}\text { Harga Dasar } \\
\text { Air }(\mathbf{R p})\end{array}$ & $\begin{array}{c}\text { Jumlah } \\
\text { Bulan }\end{array}$ & $\begin{array}{c}\text { Jumlah } \\
(\mathbf{R p})\end{array}$ \\
\hline $\mathbf{1}$ & $\mathbf{2}$ & $\mathbf{3}$ & $\mathbf{4}$ & $\mathbf{5}$ & $\mathbf{6}(\mathbf{2} \times \mathbf{3} \times \mathbf{4} \times \mathbf{5})$ \\
\hline 2015 & 66 & 250 & 1984 & 12 & $392.832 .000,00$ \\
\hline 2016 & 59 & 250 & 1984 & 12 & $351.168 .000,00$ \\
\hline 2017 & 59 & 250 & 1984 & 12 & $351.168 .000,00$ \\
\hline 2018 & 65 & 250 & 1984 & 12 & $386.880 .000,00$ \\
\hline
\end{tabular}

Sumber: Badan Pengelola Pajak dan Retribusi Daerah Kota Kendari (data diolah)

Tabel 4.4 Total Harga Air Tanah Tahun 2015-2018 Niaga Besar

\begin{tabular}{|c|c|c|c|c|c|}
\hline Tahun & $\begin{array}{c}\text { Jumlah } \\
\text { Objek } \\
\text { Pajak }\end{array}$ & $\begin{array}{c}\text { Maksimal } \\
\left(\mathbf{m}^{\mathbf{3}}\right)\end{array}$ & $\begin{array}{c}\text { Harga Dasar } \\
\text { Air }(\mathbf{R p})\end{array}$ & $\begin{array}{c}\text { Jumlah } \\
\text { Bulan }\end{array}$ & Jumlah (Rp) \\
\hline $\mathbf{1}$ & $\mathbf{2}$ & $\mathbf{3}$ & $\mathbf{4}$ & $\mathbf{5}$ & $\mathbf{6}(\mathbf{2 \times 3 \times 4 \times \mathbf { 5 } )}$ \\
\hline 2015 & 90 & 300 & 8664 & 12 & $2.807 .136 .000,00$ \\
\hline 2016 & 87 & 300 & 8664 & 12 & $2.713 .564 .800,00$ \\
\hline 2017 & 87 & 300 & 8664 & 12 & $2.713 .564 .800,00$ \\
\hline 2018 & 115 & 300 & 8664 & 12 & $3.586 .896 .000,00$ \\
\hline
\end{tabular}

Sumber: Badan Pengelola Pajak dan Retribusi Daerah Kota Kendari (data diolah)

Tabel 4.5 Total Harga Air Tanah Tahun 2015-2018 Industri Besar

\begin{tabular}{|c|c|c|c|c|c|}
\hline Tahun & $\begin{array}{c}\text { Jumlah } \\
\text { Objek Pajak }\end{array}$ & $\begin{array}{c}\text { Maksimal } \\
\left(\mathbf{m}^{\mathbf{3}}\right)\end{array}$ & $\begin{array}{c}\text { Harga Dasar } \\
\text { Air }(\mathbf{R p})\end{array}$ & $\begin{array}{c}\text { Jumlah } \\
\text { Bulan }\end{array}$ & Jumlah (Rp) \\
\hline $\mathbf{1}$ & $\mathbf{2}$ & $\mathbf{3}$ & $\mathbf{4}$ & $\mathbf{5}$ & $\mathbf{6}(\mathbf{2 \times 3 \times 4 \times 5 )}$ \\
\hline 2015 & 2 & 1400 & 7575 & 12 & $254.250 .000,00$ \\
\hline 2016 & 2 & 1400 & 7575 & 12 & $254.250 .000,00$ \\
\hline 2017 & 2 & 1400 & 7575 & 12 & $254.250 .000,00$ \\
\hline 2018 & 2 & 1400 & 7575 & 12 & $254.250 .000,00$ \\
\hline
\end{tabular}

Sumber: Badan Pengelola Pajak dan Retribusi Daerah Kota Kendari (data diolah)

Berikut disajikan rekapitulasi potensi penerimaan pajak air tanah yaitu sebagai berikut:

Tabel 4.6 Potensi Penerimaan Pajak Air Tanah Tahun 2015-2018

\begin{tabular}{|c|c|c|c|}
\hline Tahun & $\begin{array}{c}\text { Total Harga Air Tanah } \\
(\mathbf{R p})\end{array}$ & $\begin{array}{c}\text { Tarif } \\
\text { Pajak }\end{array}$ & $\begin{array}{c}\text { Potensi pajak } \\
(\mathbf{R p})\end{array}$ \\
\hline $\mathbf{1}$ & $\mathbf{2}$ & $\mathbf{3}$ & $\mathbf{4}(\mathbf{2} \times \mathbf{3})$ \\
\hline 2015 & $3.459 .753 .348,00$ & $20 \%$ & $691.950 .670,00$ \\
\hline 2016 & $3.324 .518 .148,00$ & $20 \%$ & $664.903 .630,00$ \\
\hline 2017 & $3.324 .518 .148,00$ & $20 \%$ & $664.903 .630,00$ \\
\hline 2018 & $4.233 .561 .348,00$ & $20 \%$ & $846.712 .270,00$ \\
\hline
\end{tabular}

Hasil wawancara dengan beberapa karyawan atau pemilik usaha yang memanfaatkan air tanah yang terdaftar pada BP2RD dari kelimanya semua wajib pajak rutin membayar pajak air tanah setiap bulannya namun itu pun setelah pihak fiskus yang datang menagih yaitu SPBU Martandu, Pencucian Rezky Martandu, Pabrik Roti Karunia, Rm Sari Bumi, dan Mie Pangsit 88. Wawancara berikutnya yaitu pada pemilik usaha yang masuk dalam kriteria wajib pajak air tanah tetapi tidak terdaftar sebagai wajib pajak. 
Hasil wawancara singkat pada pemilik Sean Laundry, pemilik rumah kos Azzahra Putri, Pondok Alya, Asrama Musrin dan Portal Water yang mengambil air tanah dan masuk dalam kriteria pajak air tanah diperoleh informasi bahwa wajib pajak tersebut tidak membayar pajak disebabkan karena para pemilik usaha tidak tahu bahwa air tanah dikenai pajak, sosialisasi serta survey juga tidak pernah dilakukan oleh BP2RD. Untuk pemlik kos sendiri survey sudah dilakukan tetapi hal tersebut berkaitan dengan pajak rumah kos bukan pajak air tanah. Para pemilik usaha tersebut tidak memahami kewajibannya sebagai wajib pajak air tanah. Untuk lebih jelasnya hasil wawancara pada beberapa pemilik usaha yang memanfaatkan air tanah Kota Kendari dapat dilihat pada tabel sebagai berikut:

Tabel 4.8 Hasil Wawancara Pada Pemilik Usaha Yang Memanfaatkan Air Tanah

\begin{tabular}{|c|c|c|c|c|}
\hline No & Nama usaha & $\begin{array}{l}\text { Volume } \\
\text { Pengambilan } \\
\text { air }\left(\mathbf{m}^{\mathbf{3}}\right)\end{array}$ & Keterangan & Alasan \\
\hline 1 & SPBU Martandu & 53 & Bayar pajak & \\
\hline 2 & $\begin{array}{l}\text { Pencucian } \\
\text { Rezky Martandu }\end{array}$ & 135 & Bayar Pajak & \\
\hline 3 & Sean Laundry & 258 & Tidak bayar pajak & $\begin{array}{c}\text { Tidak tahu air tanah } \\
\text { dikenakan pajak dan tidak } \\
\text { pernah disurvey BP2RD }\end{array}$ \\
\hline 4 & $\begin{array}{l}\text { Pabrik Roti } \\
\text { Karunia }\end{array}$ & 42 & Bayar pajak & \\
\hline 5 & $\begin{array}{l}\text { Kos azzahra } \\
\text { putri }\end{array}$ & $\begin{array}{l}\text { Tidak tahu } \\
\text { karena tidak } \\
\text { ada alat ukur }\end{array}$ & Tidak bayar pajak & $\begin{array}{l}\text { Tidak tahu air tanah dikenai } \\
\text { pajak, tahunya hanya pajak } \\
\text { rumah kos }\end{array}$ \\
\hline 6 & Mie Pangsit 88 & 120 & Bayar Pajak & \\
\hline 7 & $\begin{array}{l}\text { Rm. Bakso Sari } \\
\text { Bumi }\end{array}$ & 182 & Bayar Pajak & \\
\hline 8 & Asrama Musrin & Tidak tahu & Tidak bayar pajak & $\begin{array}{c}\text { Tidak tahu air tanah } \\
\text { dikenakan pajak. Tahunya } \\
\text { pajak rumah kos saja }\end{array}$ \\
\hline 9 & Pondok Alya & Tidak tahu & Tidak Bayar Pajak & $\begin{array}{l}\text { Tidak tahu air tanah } \\
\text { dikenakan pajak. Tahunya } \\
\text { pajak rumah kos saja }\end{array}$ \\
\hline 10 & Portal Water & $\begin{array}{l}\text { Hujan } 450 \mathrm{~m}^{3} \\
\text { Panas } 1500 \mathrm{~m}^{3}\end{array}$ & Tidak Bayar Pajak & $\begin{array}{l}\text { Tidak tahu air tanah } \\
\text { dikenakan pajak dan tidak } \\
\text { pernah di survey oleh } \\
\text { BP2RD }\end{array}$ \\
\hline
\end{tabular}

4.1.2 Analisis kontribusi pajak air tanah Terhadap Penerimaan Pajak Daerah

Kontribusi pajak air tanah terhadap penerimaan pajak daerah dapat diketahui dengan cara membandingkan realisasi penerimaan pajak air tanah dengan realisasi penerimaan pajak daerah yang lebih jelasnya dapat menggunakan rumus berikut ini:

$$
\text { Kontribusi }=\frac{\begin{array}{l}
\text { Realisasi Penerimaan Pajak Air Tanah } \\
\text { Tahun Ke n }
\end{array}}{\text { Realisasi Penerimaan Pajak Daerah }} \times 100 \%
$$


Dari hasil perhitungan kontribusi, kontribusi penerimaan pajak air tanah dari tahun 2015 sampai 2018 diketahui bahwa penerimaan pajak air tanah sangat kurang berkontribusi dalam meningkatkan penerimaan pajak daerah. Hal ini dapat dilihat dari tabel berikut:

Tabel 4.9 Kontribusi Penerimaan Pajak Air Tanah terhadap Penerimaan Pajak Daerah Kota Kendari tahun 2015-2018

\begin{tabular}{|c|c|c|c|c|}
\hline Tahun & $\begin{array}{c}\text { Pajak Air Tanah } \\
\text { (Rp) }\end{array}$ & $\begin{array}{c}\text { Penerimaan Pajak } \\
\text { Daerah (Rp) }\end{array}$ & $\begin{array}{c}\text { Persentase } \\
(\%)\end{array}$ & Kriteria \\
\hline 2015 & $307.641 .400,00$ & $78.228 .157 .615,00$ & 0,39 & $\begin{array}{l}\text { Sangat kurang } \\
\text { berkontribusi }\end{array}$ \\
\hline 2016 & $333.641 .500,00$ & $90.096 .062 .475,00$ & 0,37 & $\begin{array}{l}\text { Sangat kurang } \\
\text { berkontribusi }\end{array}$ \\
\hline 2017 & $358.150 .100,00$ & 100.967.114.548,00 & 0,35 & $\begin{array}{l}\text { Sangat kurang } \\
\text { berkontribusi }\end{array}$ \\
\hline 2018 & $389.705 .800,00$ & 103.213.100.708,00 & 0,37 & $\begin{array}{l}\text { Sangat kurang } \\
\text { berkontribusi }\end{array}$ \\
\hline \multicolumn{3}{|c|}{ Rata-rata } & 0,37 & $\begin{array}{l}\text { Sangat kurang } \\
\text { berkontribusi }\end{array}$ \\
\hline
\end{tabular}

Sumber: Badan Pengelola Pajak dan Retribusi Daerah Kota Kendari (data diolah)

Dilihat secara keseluruhan selama empat tahun terakhir rata-rata kontribusi yang diberikan Pajak air tanah terhadap penerimaan pajak daerah dikategorikan sangat kurang berkontribusi karena persentase kontribusi dibawah $1 \%$.

\subsection{Pembahasan}

\subsubsection{Potensi Penerimaan Pajak Air Tanah}

Berdasarkan hasil analisis potensi pajak air terlihat bahwa data potensi pajak air tanah Kota Kendari tahun 2015-2018 ternyata lebih besar dari target dan realisasi yang ada pada Badan Pengelola Pajak dan Retribusi Daerah. Tahun 2015 potensi pajak air tanah sebesar Rp691.950.670,00. Kemudian tahun 2016 potensi mengalami penurunan menjadi sebesar Rp664.903.630,00. Pada tahun 2017 potensinya Rp664.903.630,00 potensi ini sama seperti pada tahun 2016 hal ini dikarenakan tahun 2016-2017 wajib pajak yang terdaftar memliki jumlah yang sama. Selanjutnya tahun 2018, potensi penerimaan pajak air tanah meningkat menjadi Rp846.712.270,00 meningkatnya potensi ini dikarenakan tahun 2018 jumlah wajib pajak bertambah dan semakin banyak yang memanfaatkan air tanah

\subsubsection{Kontribusi Penerimaan Pajak Air Tanah Terhadap Penerimaan Pajak Daerah}

Berdasarkan tabel 4.9 dapat diketahui bahwa kontribusi penerimaan pajak air tanah terhadap Penerimaan pajak daerah tahun 2015-2018 mengalami fluktuasi. Tingkat kontribusi penerimaan pajak air tanah terhadap penerimaan daerah di Kota Kendari pada tahun 2015 yaitu sebesar 0,39\% Tahun 2016 mengalami penurunan menjadi 0,37\%. Pada tahun 2017, kembali mengalami penurunan yaitu sebesar 0,35\% Pada tahun 2018, meningkat menjadi $0,37 \%$.

Dilihat secara keseluruhan selama empat tahun rata-rata kontribusi yang diberikan Pajak air tanah terhadap penerimaan pajak daerah dikategorikan sangat kurang berkontribusi karena persentase kontribusi dibawah $1 \%$. 


\subsubsection{Kendala-Kendala Dalam Pemungutan Pajak Air Tanah}

Berdasarkan hasil wawancara dengan kordinator lapangan pajak air tanah dan pemilik usaha yang mengambil air tanah untuk keperluan usaha, penulis menyimpulkan kendala yang sering dihadapi hal penerimaan pajak air tanah adalah sebagai berikut:

1. Kurangnya Kesadaran wajib pajak akan pentingnya pajak karena masih banyak wajib pajak yang terlambat ataupun tidak membayar jika tidak ditagih dalam membayar pajak

2. Tidak adanya meteran pada pompa air untuk mengukur volume pemakaian atau pengambilan air tanah

3. Kurangnya sosialisasi, survei dan pendataan dari Badan Pengelola Pajak dan Retribusi Daerah Kota Kendari pada pemilik usaha yang menggunakan air tanah, sehingga masih banyak terdapat pemilik usaha yang menggunakan air tanah untuk komersial tetapi belum terdaftar sebagai wajib pajak air tanah.

\subsubsection{Upaya Peningkatan Penerimaan Pajak Air Tanah}

Pajak air tanah merupakan pajak yang sangat potensial jika dikelola dengan baik akan memberikan kontribusi yang cukup besar bagi penerimaan pajak daerah. Namun kontribusi pajak air tanah terhadap penerimaan pajak daerah masih sangat kurang berkontribusi. Hal tersebut karena masih kurang optimalnya pemungutan pajak air tanah dan masih banyak potensi pajak air tanah yang belum tergali sehingga pemerintah melakukan upaya-upaya dalam mengoptimalkan jumlah penerimaan pajak air tanah yaitu sebagai berikut:

1. Meninjau kembali sasaran wajib pajak air tanah mengingat Kota Kendari mengalami perkembangan dari tahun ke tahun.

2. Mengadakan sosialisasi atau pendekatan kepada masyarakat untuk meningkatkan kesadaran dalam membayar pajak

3. Memberikan reward kepada setiap wajib pajak yang tepat waktu membayar pajak, bagus pelaporan pajaknya dan datang pada saat diadakan sosialisasi,

4. Melakukan penagihan langsung dibulan berjalan terhadap wajib pajak yang tidak membayar pajak

\subsection{Kesimpulan}

\section{KESIMPULAN DAN SARAN}

Berdasarkan hasil penelitian dan pembahasan yang telah dikemukakan sebelumnya, maka dapat disimpulkan sebagai berikut:

1. Potensi penerimaan pajak air tanah yang dimiliki Kota Kendari

a. Potensi penerimaan pajak air tanah jauh lebih besar dari realisasi yang diterima oleh BP2RD.

b. Terdapat peningkatan potensi penerimaan pajak air tanah dari tahun 2015 sampai 2018 yaitu sebesar Rp154.761.600 atau 22,36\%

2. Besarnya penerimaan pajak air tanah di Kota Kendari masih sangat kurang berkontribusi terhadap penerimaan pajak daerah. Pada tahun 2015 yaitu sebesar 0,39\% dikategorikan "Sangat Kurang Berkontribusi", tahun 2016 yaitu sebesar 0,37\% juga dikategorikan "Sangat Kurang Berkontribusi", lalu tahun 2017 adalah sebesar 0,35\% dikategorikan "Sangat Kurang Berkontribusi" dan pada tahun 2018 yaitu sebesar 0,37\% dikategorikan "Sangat Kurang Berkontribusi" sehingga dari rata-rata tingkat 


\subsection{Saran}

kontribusi penerimaan pajak air tanah terhadap penerimaan pajak daerah selama 4 tahun yaitu dari tahun 2015-2018 yaitu sebesar 0,37\% yang dikategorikan "sangat kurang berkontribusi" karena persentase kontribusi dibawah $1 \%$.

1. Bagi Badan Pengelola Pajak dan Retribusi Daerah Kota Kendari

a. Melakukan monitoring serta pendataan ulang terhadap wajib pajak air tanah yang belum terdaftar sebagai wajib pajak

b. Mempercepat pengadaaan pemasangan meteran pada tiap-tiap pompa air/sumur bor

c. Badan Pengelola Pajak dan Retribusi Daerah Kota Kendari sebaiknya lebih meningkatkan sosialisasi dan penyuluhan dengan melakukan pendekatan kepada wajib pajak dengan menjelaskan mengenai arti pentingnya membayar pajak

2. Bagi Peneliti selanjutnya

Kepada peneliti selanjutnya disarankan untuk melakukan penelitian lanjutan dengan memperbanyak sampel yang dijadikan patokan perhitungan potensi pajak air tanah guna menunjukan potensi penerimaan pajak air tanah di Kota Kendari yang lebih akurat.

\section{DAFTAR PUSTAKA}

Arikunto, S. 2010. Prosedur Suatu Penelitian Praktik. Jakarta: Rineka Cipta

Febri Putra Ardana, Srikandi Kumadji, Ahmad Husaini.2016. Analisis Potensi Pajak Air Tanah dan Kontribusinya Terhadap Penerimaan Pajak Daerah (Studi Pada Dinas Pendapatan Daerah Kota Kediri tahun 2012-2014).Jurnal Perpajakan (JEJAK). Vol.8 No.1 2016

Halim, Abdul. 2007. Akuntansi Keuangan Daerah Edisi Ketiga. Jakarta: Salemba Empat

Handoko, Sri. 2013. Analisis Tingkat Efektifitas Pajak Daerah Sebagai Sumber Pendapatan Asli Daerah Kota Pontianak. Jurnal Ekonomi Daerah. Volume 1, No. 12013

Harun, H Hamrolie. 2003. Menghitung Potensi Pajak dan Retribusi daerah. Yogjakarta: BFFEYogjakarta

Herly Pangerapan, Heince Wokas. 2016. Analisa Potensi dan Efektivitas Sistem Pemungutan Pajak Parkir dan Pajak Air Tanah Sebagai Sumber Pendapatan Asli Daerah Kota Manado. Jurnal EMBA Vol.4 No.1 Maret 2016.

Kesit, Bambang Prakoso. 2005. Pajak dan Retribusi Daerah. Yogjakarta: UII Press

Kuncoro, Mudrajad. 2009. Metode Riset Untuk Bisnis \& Ekonomi. Jakarta: Erlangga

Mardiasmo. 2018. Perpajakan Edisi 2018. Yogyakarta: Andi

Pemerintah Daerah Kota Kendari. 2011. Peraturan Daerah Kota Kendari Nomor 2 tahun 2011 tentang Pajak Daerah. Kendari: Pemerintah Kota Kendari

Pemerintah Daerah Kota Kendari. 2015. Peraturan Walikota Kendari Nomor 2 Tahun 2015 Tentang Nilai Perolehan Air Tanah Sebagai Dasar Pengenaan Pajak Pengambilan dan Pemanfaatan Air Bawah Tanah. Kendari: Pemerintah Kota Kendari

Republik Indonesia. 2004. Undang-Undang Nomor 32 Tahun 2004. Tentang Pemerintah Daerah. Jakarta: Pemerintah RI

Republik Indonesia. 2004. Undang-Undang Nomor 33 Tahun 2004 tentang Perimbangan Keuangan antara Pemerintah Pusat dan Daerah. Jakarta: Pemerintah RI

Republik Indonesia. 2007. Undang-Undang Nomor 28 Tahun 2007 tentang Ketentuan Umum dan Tata Cara Perpajakan. Jakarta: Pemerintah RI

Republik Indonesia. 2009. Undang-Undang Nomor 28 Tahun 2009 tentang Pajak Daerah Dan Retribusi Daerah. Jakarta: Pemerintah RI 
Jurnal Akuntansi dan Keuangan Volume V/1/Februari 2020

ISSN (Online) : 2503-1635, ISSN (Print): 2088-4656

Sari, Diana. 2013. Konsep Dasar Perpajakan. Bandung: PT. Refika Aditama

Siahaan, Marihot Pahala, 2010. Pajak Daerah dan Retribusi Daerah. Jakarta: PT. Raja Grafindo Persada

Vannia Christiani Nesare, Jantje Tinangon, Jessy Warongan. 2016. Analisis Potensi dan Efektivitas Pungutan Pajak Air Tanah Di Kabupaten Minahasa Utara. Jurnal EMBA Vol.4 No.4 September 2016. 